\title{
HUBUNGAN KARAKTERISTIK PETANI DENGAN KOMPETENSI AGRIBISNIS PADA USAHATANI SAYURAN DI KABUPATEN KEDIRI JAWA TIMUR
}

\author{
Rini Sri Damihartini dan Amri Jahi
}

\begin{abstract}
Abstrak
Pembangunan agribisnis berawal dari kualitas petani sebagai pelaku utama. Kualitas petani berhubungan dengan karakteristik yaitu: pendidikan formal, luas lahan, pengalaman, motivasi dan modal berusahatani. Petani yang berkualitas merupakan wujud kompetensi yang dimiliki. Untuk itu, penelitian ini bertujuan: (1) Mengetahui distribusi karakteristik petani; (2) Menganalisa kompetensi agribisnis yang harus dikuasai petani dan (3) Menganalisa hubungan antara karakteristik dengan kompetensi agribisnis petani. Penelitian dirancang sebagai penelitian survey, jumlah responden 50 petani cabai, diambil secara Propotional Random Sampling. Pengumpulan data dilakukan tiga bulan dari bulan Juni sampai dengan Agustus 2004. Lokasi penelitian diambil secara purposive sampling. Analisa data dipergunakan uji Konkordasi Kendall $W$ dan deskriptif kualitatif. Hasil penelitian, mayoritas petani berpendidikan formal SMA, memiliki lahan sempit, cukup berpengalaman, motivasi sedang dan memiliki cukup modal. Aspek pengetahuan dalam kompetensi agribisnis memperoleh nilai skor tertimbang rata-rata 75, sikap 3,2 dan ketrampilan 3. Hal ini artinya, petani umumnya menguasai pengetahuan dan ketrampilan agribisnis yang harus dikuasai dan bersikap positif terhadap agribisnis yang diusahakan. Hubungan karakteristik petani dengan kompentensi agribisnis pada umumnya memilki kesepakatan tinggi. Namun, ketiga aspek pengetahan, ketrampilan dan sikap tersebut saling bebas dalam memberikan penilaian berbagai bidang agribisnis. Kesimpulan, masih ada bidang agribisnis baik pengetahuan maupun ketrampilan yang kurang dikuasai petani dan ada beberapa kegiatan penunjang kompetensi agribisnis dianggap kurang penting. Saran penelitian adalah perlu diadakan penyuluhan secara intensif mengenai pengetahuan tentang agribisnis dan pelatihan ketrampilan bagi petani.
\end{abstract}

Kata Kunci: karakteristik petani, kompetensi, agribisnis

\section{Pendahuluan}

Pembangunan agribisnis menjadi pilihan guna peningkatan ekonomi nasional. Agribisnis yang sehat dan didukung sumberdaya berkualitas menghasilkan produk pertanian berkualitas tinggi dan mampu bersaing dengan produk-produk import.

Permasalahan saat ini Indonesia dibanjiri produk import yang merugikan petani. Untuk itu, perlu upaya peningkatan kualitas petani dengan cara meningkatkan kompetensi agribisnis agar dapat mengelola agribisnis dengan baik dan dapat bersaing di era global.

Pembangunan agribisnis berawal dari kualitas petani sebagai pelaku utama dan petani berkualitas berhubungan dengan karakteristik seperti: pendidikan formal, luas lahan, pengalaman, motivasi dan ketersediaan modal usahatani. Berdasarkan hal tersebut, maka permasalahan penelitian ini adalah:

(1) Bagaimana distribusi petani pada 
sejumlah karakteristik yang diamati?

(2) Kompetensi agribisnis sayuran apa yang harus dikuasai petani?

(3) Seberapa jauh hubungan karakteristik petani dengan kompetensi agribisnis?

Berdasarkan pada masalah, maka tujuan penelitian ini adalah:

(1) Untuk megetahui distribusi karakteristik petani

(2) Untuk menganalisa kompetensi agribisnis yang harus dikuasai oleh petani

(3) Untuk menganalisa hubungan karakteristik dengan kompetensi agribisnis

\section{Tinjauan Pustaka}

$\underline{\text { Petani }}$

Petani adalah pelaku utama agribisnis, baik agribisnis monokultur maupun polikultur dengan komoditas tanaman pangan, hortikultura, peternakan, perikanan dan atau perkebunan (Departemen Pertanian, 2002: 6).

\section{$\underline{\text { Karakteristik petani }}$}

Karakteristik individu adalah bagian dari pribadi dan melekat pada diri seseorang. Karakteristik ini mendasari tingkah laku seseorang dalam situasi kerja maupun situasi yang lainnya (Rogers dan Shoemaker, 1971: 26).

\section{Pendidikan Formal}

Mardikanto (1990: 213), menyatakan bahwa pendidikan petani umumnya mempengaruhi cara dan pola pikir petani dalam mengelola usahatani. Pendidikan yang relatif tinggi menyebabkan petani lebih dinamis

Luas Lahan usahatani

Lahan merupakan sarana produksi bagi usahatani, termasuk salah satu faktor produksi dan pabrik hasil pertanian. Lahan adalah sumberdaya alam fisik yang mempunyai peranan sangat penting bagi petani (Mosher, 1965: 23). $\underline{\text { Pengalaman Usahatani }}$

Padmowihardjo

(1994: 22), mengemukakan bahwa pengalaman baik yang menyenangkan maupun mengecewakan berpengaruh pada proses belajar seseorang.

Motivasi Berusahatani

Motivasi merupakan usaha yang dilakukan oleh manusia untuk menimbulkan dorongan berbuat atau melakukan tindakan. Motivasi dapat menjelaskan alasan seseorang melakukan sesuatu tindakan (Padmowihardjo, 2002: 34).

\section{Ketersediaan Modal Usahatani}

Modal adalah faktor penunjang utama dalam kegiatan berusahatani. Hal ini dikarenakan tanpa modal usahatani niscaya petani akan sulit mengembangkan usahatani yang dilakukan (Wolf, 1985: 21).

\section{Pengertian Usahatani dan Agribisnis}

Usahatani menurut Mosher (1965: 12), adalah himpunan sumber-sumber alam yang terdapat di permukaan bumi tempat pertanian diselenggarakan oleh petani tertentu. Agribisnis adalah suatu sistem yang terpadu dan terdiri dari empat sub-sistem yang terintegrasi secara fungsional. Sub-sistem pertama disebut agribisnis hulu, Kedua, adalah pertanian primer (on-farm), ketiga, agribisnis hilir, berupa kegiatan pengolahan hasil usaha dan perdagangan dan ke-empat adalah lembaga jasa (Departemen Pertanian, 2002: 5).

\section{Kompetensi}

Kompetensi merupakan kemampuan untuk melaksanakan tugas-tugas secara efektif dan merupakan refleksi dari kinerja yang dilakukan seseorang dalam menyelesaikan tugas dan pekerjaannya (Boyatzis, 1982: 11).

\section{Kompetensi Agribisnis Yang Perlu Dikuasai Petani}

$\underline{\text { Kompetensi Tehnis Petani sebagai Jurutani }}$

Kompetensi tehnis petani sebagai jurutani adalah: (1) bercocok-tanam, (2) perlakuan benih/bibit, (3) Pemupukan, (4) Pengairan, (5) Pengendalian hama dan 
penyakit, (6) Panen, (7) Pasca panen.

$\underline{\text { Kompetensi Khusus Petani sebagai Manajer }}$ Usahatani

Peran manajer dalam usahatani menuntut petani harus mampu berusaha mengambil keputusan. Kemampuan pengambilan keputusan yang harus dikuasai oleh petani sebagai manajer (Mosher, 1965: 15): (1) menentukan varietas benih unggul, (2) menentukan jenis tanaman yang diusahakan, (3) mengembangkan jiwa wirausaha, (4) meningkatkan keuntungan terus menerus dari usahataninya, (5) mengindentifikasi faktor penghambat dan pendukung, (6) memilih informasi yang dibutuhkan.

Kompetensi Agribisnis Petani Sayuran Yang $\underline{\text { Harus Dikuasai }}$

Petani agribisnis dituntut mampu bertanggung jawab dalam hal: (1) merencanakan biaya produksi, (2) pemilihan komoditas, (3)penggunaan sumberdaya lahan secara efisien, (4) menggunakan tehnologi baru secara efisien dan (5) Mampu menghitung keuntungan.

\section{Hubungan Karakteristik Petani dengan Kompetensi Agribisnis}

\section{Pendidikan Formal}

Suparta (2001: 142-143), dalam penelitiannya menyatakan bahwa terdapat kecenderungan usaha agribisnis ayam diminati peternak dengan tingkat pendidikan formal menengah keatas bahkan hingga pasca-sarjana.

\section{Luas Lahan Usahatani}

Lahan usahatani sempit menjadi kendala bagi penerapan sistem usahatani secara intensif, dan menyebabkan petani kurang mampu dalam penerapan tehnologi pertanian serta pengelolaan usahatani secara komersial (Mardikanto, 1993: 30-31).

\section{Pengalaman Usahatani}

Penelitian oleh Pambudy (1999: 123), mengemukakan bahwa keberhasilan peternak dalam beragribisnis ayam buras berhubungan dengan pengalaman beternak petani.

\section{Motivasi Berusahatani}

Rogers dan Shoemaker (1971: 21), mengemukakan bahwa jika seseorang sadar akan kebutuhan yang dirasakan maka akan berusaha mencari inormasi-inforasi mengenai hal-hal baru, inovasi baru, guna untuk memenuhi kebutuhannya.

\section{$\underline{\text { Ketersediaan Modal Usahatani }}$}

Ketersediaan modal usahatani bagi petani berhubungan erat dengan tingkat keberhasilan pengelolaan usahatani. Hal ini disebabkan, ketersediaan modal usahatani merupakan sumber kekuatan utama bagi proses produksi (Mardikanto, 1983: 33).

\section{Metode Penelitian}

\section{Populasi dan Sampel}

Populasi penelitian ini adalah petani cabai di Kabupaten Kediri, responden diambil secara Proportional Random Sampling sebanyak 50 petani.

$\underline{\text { Pengumpulan Data }}$

Pengumpulan data dilakukan di tujuh kecamatan yaitu Kecamatan Pagu, Plemahan, Wates, Kepung, Pare, Gurah dan Kecamatan Papar.

\section{Analisis Data}

Untuk menganalisa data yang terkumpul dipergunakan uji Konkordasi Kendall $W$ dan dilakukan analisa kualitatif deskriptif.

\section{Hasil dan Pembahasan}

\section{Distribusi Karakteristik Petani}

Karakteristik petani yang diamati ialah: 1) Pendidikan Formal, (2) Luas Lahan, (3) Pengalaman Berusahatani, (4) Motivasi Berusahatani dan (5) Ketersediaan Modal Usahatani. Distribusi karakteristik dapat dilihat pada Tabel 1.

Tabel 1 menggambarkan bahwa pendidikan formal petani 56 persen SMA atau sederajat. 45 persen petani memiliki lahan sempit dan ternyata petani cukup berpengalaman dan memiliki ketersediaan 
modal.

\section{Kompetensi Agribisnis Cabai Petani}

Tigabelas bidang kompetensi yang harus dikuasai petani: (1) Bercocok Tanam, (2) Perlakuan Benih/bibit, (3) Pemupukan, (4) Pengairan, (5) Pengendalian Hama dan Penyakit, (6) Perencanaan Biaya Produksi, (7) Pemilihan Komoditas, (8) Pemanfaatan Lahan Secara Efisien, (9) Kendala dan Peluang Usahatani, (10) Penggunaan Tehnologi Secara Efisien, (11) Panen, (12) Pasca Panen, (13) Kewirausahaan.
Perlakuan Benih/bibit.

$\underline{\text { Sikap Petani terhadap agribisnis cabai }}$

Hasil penelitian memberi gambaran bahwa petani menganggap penting : 1) Perlakuan benih/bibit, 2) Pemilihan Komoditas dan 3) Kewirausahaan. Sementara, kurang penting: 1) Perencanaan Biaya Produksi, 2) Pemanfaatan Lahan Secara Efisien dan 3) Penggunaan tehnologi secara efisien.

Tabel 1. Distribusi Karakteristik Petani

\begin{tabular}{|c|c|c|c|c|}
\hline ;klp & Karakteristik & Kategori & Jumlah & $\begin{array}{l}\text { Persentase } \\
(\%)\end{array}$ \\
\hline 1. & $\begin{array}{l}\text { Pendidikan } \\
\text { Formal }\end{array}$ & $\begin{array}{l}\text { Rendah: } 6-9 \text { Thn } \\
\text { Sedang: } 10-14 \text { Thn } \\
\text { Tinggi: } 15-19 \text { Thn }\end{array}$ & $\begin{array}{l}11 \\
28 \\
11\end{array}$ & $\begin{array}{l}22 \\
56 \\
22\end{array}$ \\
\hline 2. & Luas lahan & $\begin{array}{ll}\text { Sempit: } & 0,2-2,1 \mathrm{Ha} \\
\text { Luas: } & >2,1 \mathrm{Ha}\end{array}$ & $\begin{array}{r}45 \\
5\end{array}$ & $\begin{array}{l}90 \\
10\end{array}$ \\
\hline 3. & $\begin{array}{l}\text { Pengalaman } \\
\text { Berusahatani }\end{array}$ & $\begin{array}{llll}\text { Kurang: } & <9 & \text { Thn } \\
\text { Cukup: } & >9 & \text { Thn }\end{array}$ & $\begin{array}{l}23 \\
27\end{array}$ & $\begin{array}{l}46 \\
54\end{array}$ \\
\hline 4. & $\begin{array}{l}\text { Motivasi } \\
\text { Berusahatani }\end{array}$ & $\begin{array}{lr}\text { Rendah: Skor } & 5-10 \\
\text { Tinggi: Skor } 11-20\end{array}$ & $\begin{array}{l}17 \\
33\end{array}$ & $\begin{array}{l}34 \\
66\end{array}$ \\
\hline 5. & $\begin{array}{l}\text { Ketersediaan } \\
\text { Modal }\end{array}$ & $\begin{array}{lr}\text { Kurang: Skor } & 5-10 \\
\text { Cukup: Skor } & 11-15 \\
\text { Banyak: Skor } & 16-20\end{array}$ & $\begin{array}{r}11 \\
31 \\
8\end{array}$ & $\begin{array}{l}22 \\
62 \\
16\end{array}$ \\
\hline
\end{tabular}

Pengetahuan petani tentang agribisnis cabai

Hasil penelitian memberikan gambaran, pengetahuan tergolong tinggi adalah: 1) Perlakuan Benih/bibit, 2) Pemupukan, 3) Identifikasi kendala dan peluang. Bidang lainnya tergolong rendah: 1) Perencanaan Biaya Produksi, 2) Pemilihan Komoditas dan 3) Pemanfaatan Lahan Secara Efisien.

Ketrampilan Petani Beragribisnis cabai

Hasil penelitian menyatakan ketrampilan tergolong tinggi adalah: 1) Kewirausahaan, 2) Bercocok tanam dan 3) Pemupukan. Selanjutnya, yang tergolong rendah meliputi: 1) Pemanfaatan Lahan Secara Efisien, 2) Pasca Panen dan 3)

\section{Hubungan Karakteristik Petani dengan Pengetahuan Agribisnis Cabai}

Hubungan Pendidikan Formal dengan Pengetahuan Petani tentang Agribisnis Cabai

Petani berpendidikan rendah, pengetahuan yang penting ialah: 1) Perlakuan Benih/bibit, 2) Panen dan 3) Identifikasi kendala dan Peluang. Petani berpendidikan sedang, pengetahuan paling penting ialah: 1) Panen, 2) Kewirausahaan dan 3) Pemupukan. Selanjutnya, petani berpendidikan tinggi pengetahuan paling penting ialah: 1) Perlakuan Benih/bibit, 2) identifikasi kendala dan peluang dan 3) Panen. Selanjutnya bidang: 1) Bercocok tanam, 2) Pemupukan 
dan 3) Pasca panen dianggap kurang penting.

Hubungan Luas Lahan Petani dengan

Pengetahuan Petani tentang Agribisnis Cabai

Hasil penelitian, petani dengan lahan sempit pengetahuan yang paling penting ialah: 1) Panen, 2) Perlakuan Benih/bibit dan 3) Identifikasi kendala dan Peluang. Bagi petani yang lahannya luas pengetahuan paling penting ialah: 1) Identifikasi kendala dan peluang, 2) Kewirausahaan, 3) Perlakuan benih/bibit dan 4) Pengendalian Hama dan Penyakit. Selanjutnya, pengetahuan seperti: 1) Perencanaan biaya produksi, 2) Pemilihan komoditas dan 3) Penggunaan lahan secara efisien dianggap kurang penting.

Hubungan Pengalaman Berusahatani Petani dengan Pengetahuan Petani tentang Agribisnis Cabai

Hasil penelitian menjelaskan petani kurang pengalaman pengetahuan paling penting ialah: 1) Perlakuan Benih/bibit, 2) Pemanenan dan 3) Identifikasi kendala dan peluang. Bagi petani cukup pengalaman pengetahuan paling penting ialah: 1) Perlakuan Benih/bibit, 2) Pemanenan 3) Identifikasi kendala dan peluang. Selanjutnya, ketiga kelompok petani menganggap kurang penting untuk 1) Perencanaan biaya produksi, 2) Pemilihan komoditas dan 3) Pemanfaatan lahan secara efisien.

Hubungan Motivasi Berusahatani Cabai Petani dengan Pengetahuan Petani tentang Agribisnis Cabai

Hasil penelitian menjelaskan petani bermotivasi rendah pengetahuan yang paling penting ialah: 1) Identifikasi kendala dan peluang,2) Kewirausahaan dan 3) Panen. Petani bermotivasi tinggi pengetahuan yang paling penting ialah: 1) Perlakuan Benih/bibit, 2) Panen dan 3) Identifikasi kendala dan peluang.

Selanjutnya petani membuat jenjang lebih rendah pada bidang: 1) Perencanaan biaya produksi,2) Pemilihan komoditas Cabai, dan 3) Pemanfaatan lahan secara efisien.

Hubungan Ketersediaan Modal Berusahatani Petani dengan Pengetahuan Petani tentang
Agribisnis Cabai

Petani yang kurang modal pengetahuan yang paling penting ialah: 1) Pemanenan Cabai, 2) Penggunaan tehnologi secara efisien dan 3) Kewirausahaan. Bagi petani yang cukup modal pengetahuan yang paling penting ialah: 1) Perlakuan Benih/bibit cabai, 2) Kendala dan peluang usahatani cabai, 3) Pemanenan Cabai dan 4) Kewirausahaan. Selanjutnya, bagi petani yang banyak modal pengetahuan yang paling penting ialah: 1) Panen, 2) Pemupukan, 3) Identifikasi kendala dan peluang usahatani cabai, dan 4) Perlakuan Benih/bibit cabai. Selanjutnya kelompok ini membuat jenjang yang lebih rendah pada bidang pengetahuan tentang agribisnis lainnya, seperti: 1) Bercocok tanam cabai, 2) Pemupukan dan 3) Pengairan.

\section{Hubungan Karakteristik Petani dengan Ketrampilan Beragribisnis Cabai}

Hubungan Pendidikan Formal Petani dengan Ketrampilan Beragribisnis Cabai

Hasil penelitian menjelaskan petani berpendidikan formal rendah, bidang ketrampilan paling penting ialah: 1) Penggunaan tehnologi secara efisien, 2) Pengendalian Hama dan Penyakit dan 3) Kewirausahaan. Sementara bagi petani berpendidikan formal sedang, ketrampilan paling penting ialah: 1) Pengendalian Hama dan Penyakit, 2) Kewirausahaan, 3) Pemupukan dan 4) Bercocok tanam cabai. Selanjutnya, bagi petani berpendidikan formal tinggi, ketrampilan yang paling penting ialah: 1) Perencanaan biaya produksi, 2) Penggunaan Tehnologi secara efisien dan 3) Kewirausahaan. Sementara, bidang ketrampilan lainnya seperti: 1) Penggunaan lahan secara efisien, 2) Kendala dan peluang, 3) Perlakuan benih/bibit diberi jenjang lebih rendah.

Hubungan Luas Lahan Petani dengan Ketrampilan Petani Beragribisnis Cabai

Hasil penelitian, petani lahan sempit, ketrampilan paling penting ialah: 1) Pengendalian Hama dan Penyakit, 2) Penggunaan tehnologi secara efisien dan 3) Kewirausahaan. Selanjutnya, petani lahan 
luas, ketrampilan paling penting ialah: 1) Penggunaan Tehnologi secara efisien, 2) Kewirausahaan dan 3) Bercocok tanam. Selanjutnya ketrampilan seperti: 1) Perlakuan benih/bibit cabai, 2) Pasca panen dan 3) Identifikasi kendala dan peluang usahatani cabai diberi jenjang lebih rendah.

Hubungan Pengalaman Berusahatani Cabai

Petani dengan Ketrampilan Petani

Beragribisnis Cabai

Hasil penelitian menjelaskan petani kurang berpengalaman, ketrampilan yang paling penting ialah: 1) Pengendalian Hama dan Penyakit cabai, 2) Kewirausahaan dan 3) Pemupukan. Sementara petani yang cukup berpengalaman, ketrampilan yang paling penting ialah: 1) Penggunaan tehnologi secara efisien, 2) Kewirausahaan dan 3) Perencanaan biaya produksi cabai. Selanjutnya, bidang kerampilan lainnya seperti: 1) Perlakuan benih/bibit cabai, 2) Pasca panen cabai dan 3) Pemanfaatan lahan secara efisien diberi jenjang yan lebih rendah.

Hubungan Motivasi Berusahatani Cabai

Petani dengan Ketrampilan Petani

Beragribisnis Cabai

Hasil penelitian menjelaskan petani bermotivasi rendah, ketrampilan paling penting ialah: 1) Penggunaan tehnologi secara efisien, 2) Pengendalian Hama dan Penyakit cabai dan 3) Kewirausahaan. Sementara petani bermotivasi tinggi, ketrampilan yang paling penting ialah: 1) Kewirausahaan, 2) Perencanaan biaya produksi dan 3) Pengendalian hama dan penyakit. Selanjutnya, bidang lainnya seperti: 1) Bercocok tanam, 2) Perlakuan benih/bibit, dan 3) Pemupukan menempati jenjang yang lebih rendah.

Hubungan Ketersediaan Modal Usahatani

Cabai dengan Ketrampilan Petani

Beragribisnis Cabai

Hasil penelitian menjelaskan petani kurang modal, ketrampilan paling penting ialah: 1) Perencanaan biaya, 2) Pengendalian Hama dan Penyakit dan 3) Penggunaan tehnologi secara efisien. Sementara bagi petani yang cukup modal, ketrampilan paling penting ialah: 1) Bercocok tanam cabai, 2) Kewirausahaan dan 3) Pengendalian Hama dan Penyakit cabai. Selanjutnya, bagi petani banyak modal, ketrampilan agribisnis paling penting ialah:1) Pengendalian hama dan penyakit, 2) Penggunaan Tehnologi secara efisien dan 3) Kewirausahaan. Selanjutnya bidang kerampilan agribisnis lainnya seperti: 1) Bercocok tanam, 2) Perlakuan benih/bibit dan 3) Pemupukan berada pada jenjang lebih rendah.

\section{Hubungan Karakteristik dengan Sikap Terhadap Agribisnis Cabai}

Hubungan Pendidikan Formal Petani dengan

Sikap Petani terhadap Agribisnis Cabai

Hasil penelitian menjelaskan petani berpendidikan formal rendah, sikap paling penting ialah: 1) Perlakuan Benih/bibit, 2) Pemilihan komoditas dan 3) Panen. Sementara petani berpendidikan sedang, sikap paling penting ialah: 1) Perlakuan terhadap benih/bibit , 2) Pemilihan komoditas, 3) Pemupukan dan 4) Bercocok tanam. Selanjutnya, petani berpendidikan ftinggi, sikap paling penting ialah: 1) Perlakuan Benih/bibit, 2) Bercocok tanam, 3) Pengairan dan 4) Pasca Panen. Selanjutnya, bidang lainnya, seperti: 1) Pemupukan, 2) Pengairan dan 3) Pengendalian hama dan penyakit dianggap kurang penting.

Hubungan Luas lahan Petani dengan Sikap

Petani terhadap Agribisnis Cabai

Hasil penelitian menjelaskan petani lahan sempit, sikap paling penting ialah: 1) Perlakuan Benih/bibit, 2) Bercocok tanam, 3) Pemupukan dan 4) Pemilihan komoditas. Sementara petani lahan luas, sikap paling penting ialah: 1) Pemilihan komoditas, 2) Pasca panen dan 3) Kewirausahaan. Sementara itu: 1) Pengairan, 2) Pengendalian hama dan penyakit cabai dan 3) Perencanaan biaya produksi dianggap kurang penting.

Hubungan Pengalaman Berusahatani Cabai dengan Sikap Petani terhadap Agribisnis Cabai

Hasil penelitian menjelaskan petani kurang berpengalaman, sikap yang paling 
penting ialah: 1) Perlakuan Benih/bibit cabai, 2) Pemupukan dan 3) Bercocok tanam cabai. Selanjutnya, petani yang cukup berpengalaman, sikap paling penting ialah: 1) Perlakuan Benih/bibit cabai, 2) Pemilihan komoditas cabai dan 3) Kewirausahaan. Sementara itu: 1) Pengairan, 2) Pengendalian hama dan penyakit tanaman cabai, 3) Perencanaan biaya produksi cabai dan 4) Pemilihan komoditas cabai dianggap kurang penting.

Hubungan Motivasi Berusahatani Cabai

Petani dengan Sikap Petani terhadap

Agribisnis Cabai

Hasil penelitian menjelaskan bagi petani bermotivasi rendah, sikap yang paling penting ialah: 1) Pemilihan komoditas cabai, 2) Perlakuan Benih/bibit dan 3) Pemupukan. Selanjutnya, bagi petani yang bermotivasi tinggi, sikap yang paling penting ialah: 1) Perlakuan Benih/bibit cabai, 2) Pemupukan dan 3) Bercocok tanam cabai. Sementara: 1) Pengairan, 2) Pengendalian hama dan penyakit cabai dan 3) Perencanaan biaya produksi dianggap kurang penting.

\section{Hubungan Ketersediaan Modal Berusahatani Cabai}

Petani dengan Sikap Petani terhadap

Agribisnis Cabai

Hasil penelitian, petani kurang modal sikap yang paling penting ialah: 1) Pemupukan, 2) Bercocok tanam dan 3) Perlakuan Benih/bibit. Sementara bagi petani cukup modal, sikap yang paling penting ialah: 1) Pemilihan komoditas, 2) Perlakuan benih/bibit, 3) Pemupukan dan 4) Kewirausahaan. Selanjutnya, petani bermodal sikap yang paling penting ialah: 1) Perlakuan benih/bibit, 2) Bercocok tanam dan 3) Pemilihan komoditas. Sementara, bidang agribisnis lainnya, seperti: 1) Pengairan, 2) Pengendalian hama dan penyakit dan 3) Perencanaan biaya produksi dianggap kurang penting.
Hubungan Pengetahuan, Sikap dan

Ketrampilan dalam Kompetensi Petani Beragribisnis Cabai

Hasil penelitian menunjukkan aspek pengetahuan, ketrampilan dan sikap, memiliki kesepakatan rendah, dengan kata lain aspekaspek tersebut saling bebas dalam menilai bidang agribisnis yang harus dikuasai petani.

\section{Pembahasan}

Kompetensi Agribisnis Petani

Aspek pengetahuan diperoleh nilai ratarata sebesar 75, artinya petani menguasai pengetahuan tentang agribisnis cabai. Pengetahuan tersebut meliputi: 1) Bercocok tanam, 2) Perlakuan benih/bibit dan 3) Pemupukan. Sedangkan yang kurang dikuasai adalah: (1) Pemanfaatan lahan secara efisien, (2) Perencanaan biaya produksi dan (3) Pemilihan jenis komoditas.

Hasil penelitian mengenai ketrampilan menunjukkan skor rata-rata sebesar 3.0, artinya petani relatif trampil. Ketrampilan agribisnis yang dikuasai: 1) Bercocok tanam, 2) Pemupukan dan 3) Pengairan. Sedangkan yang kurang dikuasai meliputi: Pemanfaatan lahan secara efisien, (2) Pasca panen dan (3) Perlakuan benih/bibit.

Pada aspek sikap diperoleh rata-rata sebesar 3,2, artinya petani pada umunya bersikap positif terhadap bidang agribisnis yang harus dikuasai. Sikap positif tersebut seperti: 1) Bercocok tanam, 2) Perlakuan benih/bibit dan 3) Pemupukan. Sedangkan yang dianggap kurang penting: (1) Pengendalian hama dan penyakit, 2) Identifikasi kendala dan peluang usahatani dan (3) Penggunaan tehnologi secara efisien.

Hubungan Karakteristik dengan Kompetensi Agribisnis Petani

Hubungan karakteristik petani dengan aspek pengetahuan dan ketrampilan memiliki tingkat kesepakatan tinggi dalam melakukan penjenjangan kompetensi agribisnis cabai yang harus dikuasai petani. Sementara, hubungan karakteristik dengan aspek sikap relatif tidak erat, hal ini ditunjukkan kecilnya nilai $W$. 
Hubungan Pengetahuan, Ketrampilan dan Sikap dalam Kompetensi Agribisnis Petani

Berdasarkan hasil penelitian ternyata pengetahuan, sikap dan ketrampilan memiliki kebebasan dalam menilai bidang agribisnis cabai yang harus dikuasai oleh petani. Hal ini sesuai dengan pendapat Gonzalez dalam Jahi (1993: 17), bahwa meskipun dimensi efek kognitif, afektif dan konatif berhubungan satu sama lain, namun ketiganya juga independen satu sama lain.

\section{Kesimpulan}

Berdasarkan pembahasan dikemukakan kesimpulan sebagai berikut:

(1) Kompetensi agribisnis cabai yang harus dikuasai petani adalah:

a) Pengetahuan yaitu: (1) Perencanaan biaya produksi, (2) Pemanfaatan lahan secara efisien dan (3) Pemilihan jenis komoditas.

b) Sikap yaitu: (1) Pengendalian Hama dan Penyakit, Pemupukan dan (3) Pengunaan tehnologi secara efisien.

c) Ketrampilan yaitu: (1) Pemanfaatan lahan secara efisien, (2) Pasca panen dan (3) Perlakuan benih/bibit.

(2) Aspek pengetahuan, sikap dan ketrampilan saling bebas dalam melakukan penilaian terhadap bidangbidang agribisnis yang harus dikuasai petani.

\section{Rujukan}

Jahi, Amri. 1993. "Komunikasi dan Pembangunan". Dalam Komunikasi Massa Dan Pembangunan Pedesaan Di Negara-negara Dunia Ketiga: suatu Pengantar. Disunting oleh Amri Jahi. Jakarta. PT. Gramedia.

Mardikanto. T. 1993. Penyuluhan Pembangunan Pertanian. Surakarta: Sebelas Maret University Press.
Mosher, A.T. 1987. Menggerakan dan Membangun Pertanian. Yogyakarta. CV Yasaguna.

Padowihardjo, 2004. Pengembangan SDM Dalam Sistem Dan Usaha Agribisnis. Pusat Pendidikan Dan Pelatihan Pegawai Departemen Pertanian. Jakarta. 